adjunktus

SZTE ÁJTK

\title{
A szülöi felügyelet tartalmának és rendezésének jogtörténeti fejlődése Magyarországon a 19-20. században
}

\section{The Historical Development of Child Custody Decisions in Hungary in the $19^{\text {th }}$ and $20^{\text {th }}$ Century}

Parental responsibility has undergone dramatic changes since the Roman times when the pater familias could decide even upon child's life. Mothers didn't have rights, they also lived under their husband's power. The unlimited power of fathers existed till the medieval times. It was John Locke who first said that the mother and the father should exercise parental rights together, although this principle turned into practice only centuries later. The situation in Hungary was formed similarly as well. After taking up Christian religion father's rights weakened, while their obligations enhanced. However fathers still had prior rights to mothers. By the $19^{\text {th }}$ century the paternal power had changed. The protection of children's rights and interests slowly and gradually appeared. Obligations showed up before rights. The family law act in 1952 brought the biggest changes. Parental power turned into parental custody. The child custody decisions were unimportant for a long time as the father had all the rights and the parents' divorce was not common. First the matrimonial act in 1894 regulated it in more detail. Back then, the focus was on which parent was guilty in wrecking the marriage. In 1940 it was Kálmán Csorna who pointed out that guiltiness shouldn't play a role, we should investigate child's best interest instead. After several amendments the family law regulations softened. The law said that if the parents live together, they exercise their rights together. If they split up only one parent exercises all the rights exclusively. The other parent's rights are paused, they only have the right of visitation and the obligation of paying maintenance. Although the parents should have had to cooperate in the favour of the child, it was not always successful. The regulations of parental rights and child custody decisions changed very slowly during the centuries but this change has speeded up recently. From the ancient times there was paternal power for a long time which switched to parental power in the $19^{\text {th }}$ century, and to parental custody in the $20^{\text {th }}$ century, finally to parental responsibility in the $21^{\text {st }}$ century. The difference is not only based on the level of words. In 2019 it is not a question anymore that during exercising parental rights and child custody decisions it is the child's best interest which is the main point. In this essay I focus on the following questions: how the legislator reacted to the changes in society as the role of children in the family and male-female relationships that caused problems which had to be solved.

Keywords: parental power, parental custody, parental responsibility, child custody decisions, child's best interest

\section{Bevezetés}

Az emberiség történelme során, a kezdetektől fogva napjainkig, mindvégig evidenciának számított, hogy a szülőknek különleges szerepe van a gyermekek életében, és vitathatatlan, hogy ebben a szerepben bizonyos jogokkal és kötelességekkel bírnak gyermekeik vonatkozásában. 
Ezen jogok és kötelességek tartalma, terjedelme, gyakorlásának módja és a - szülők kapcsolatának megváltozása esetén - annak rendezése azonban sokat változott, elsősorban az elmúlt évszázadban. A szülői szerepből eredő kiváltságok sokáig elsősorban jogokat jelentettek, melyek egyúttal a gyermek feletti szinte korlátlan uralmat is megjelenítették. A szülők kötelességei csak jóval később kerültek előtérbe, mint ahogy a felügyelet gyakorlásának módja, illetve annak rendezése sem vetett fel sokáig kérdéseket, hiszen természetes volt, hogy a szülő elsősorban az apa, és nem vitás, hogy a szülôk kapcsolata is csak a halállal szűnhetett meg.

A szülőpár - mint anya és apa - kapcsolata, a családok létrejötte, a gyermekek száma, szerepük és megbecsültségük a családban, az apai, majd szülői hatalom gyakorlásának módja jogi, pszichológiai és szociológiai szempontból is külön-külön nagyívú tanulmányok témája lehetne, akár korszakonként megvizsgálva a kérdést. Érdemes lenne továbbá nem csak a hazai változásokat nyomon követni, hanem nemzetközi kitekintést is tenni, elsősorban az osztrák, illetve német utakat bemutatva. Jelen tanulmány szerény keretei között a téma egy apró szeletére kívánok bepillantást engedni és csak a legutóbbi időszak - a korábbiakhoz képest - gyorsan lezajlott és nagyon jelentős változásait bemutatni. Kutatásom során több kérdés is megfogalmazódott bennem, melyekre igyekeztem választ találni. Ehhez vezérfonalként a jogszabályokat használtam fel, azok változásait mutatom be, melyeket igyekeztem kiegészíteni az adott törvényhez kapcsolódó kommentárokkal és tankönyvekkel. Fontosnak tartom végig követni, hogy miként reagált a jogalkotó a társadalomban lezajlott változásokra. Az évezredes hagyományok egy csapásra változtak meg a 19. század végén, amikor elindult a folyamat, melynek eredményeképpen minden családban egyre kevesebb gyermek születik, 1́gy megbecsültségük nőtt, a családban betöltött szerepük megváltozott. Ehhez kellett igazítani a szülői jogokat és kötelességeket is. A férfi-nő kapcsolat is gyökeres átalakuláson ment keresztül, ez hatással volt az anya és az apa jogainak gyakorlására is. A házasság lényege, fontossága is átértékelődött, a kapcsolatok egyre bomlékonyabbá váltak, emiatt a szülói felügyelet rendezése, azaz a gyermek elhelyezése is megkerülhetetlenül bekerült a szabályozandó kérdések körébe.

Kutatásom során áttekintettem és jelen tanulmányban röviden bemutatom a szülői felügyelet tartalmának jelentősebb változásait, a gyakorlásának módjában lezajlott fejlődési ívet, valamint a gyermekelhelyezésre vonatkozó szabályok alakulását a vétkességi alapú döntésektôl a közös szülői felügyeletig. Tanulmányom keretei között a hazánkban bekövetkezett jogszabályi változások felvázolására törekedtem, de további lehetőségek rejlenek a téma levéltári kutatásában, annak érdekében, hogy még mélyebben megismerhessük, miként alkalmazták a szabályokat a gyakorlatban.

\section{A szülői felügyelet tartalmának jogtörténeti fejlődése}

A szülői felügyeleti jogkör tartalma jelentős változáson ment keresztül az elmúlt évszázadokban. Az ókori Rómában a családfó, a pater familias a gyermek élete felett is rendelkezhetett, akár el is adhatta vagy meg is ölhette gyermekét (Ius vitae acnecis). Az atyai hatalom teljes korlátlansága egészen a középkorig fennállt, így a gyermek mindenekfelett álló érdekének ${ }^{1}$ biztosítása csupán később, a gyermeki jogok kialakulását követően vált irányadó alapelvvé. John Locke az elsők között

\footnotetext{
${ }^{1}$ Child’s best interest. Ma már leginkább a következô fordítást használjuk: a gyermek legfőbb érdeke vagy legjobb
} érdeke. 
volt, aki szakítva a korábbi nézetekkel, kijelentette, hogy a szülői hatalmat az anya és az apa együttesen képviselik, és megosztva gyakorolják. Bár e megállapítás nagy horderejű volt, gyakorlati megvalósulásáig még hosszú idő telt el.

Magyarországon a honfoglalást követően a kereszténység felvételének következtében sokat gyengültek az atyák jogai, a gyermekek irányában fennálló kötelességeik viszont szaporodtak. I. István törvénykönyvében így rendelkezett: „A₹ atyák ugyanis azért atyák, hogy táplálják gyermekeiket, ha pedig az, atya már nem él, úgy az öquegy nő köteles gondozni”. A gondozás azonban nem jelentette azt, hogy ne lehetne a gyermeket adósság fejében rabszolgának adni. Werbő́çy István Hármaskönyve (1514) sem tekinthető még a gyermekek jogai védelmezôjének: biztosította az atya számára az egész háza népe feletti hatalmat, gyermekét bármikor bezárhatta, sőt, fenyítési jog (disciplina domestica) is megillette, persze csak olyan mértékben, amely a gyermek egészségére ártalmatlan. A gyermek csak akkor szabadult e hatalom alól, ha elköltözött atyja házából és képes volt magát eltartani. A gyermek nevelésének és eltartásának kötelezettsége azonban nem szerepelt a törvénykönyvben, mert ezt természetesnek tekintették. ${ }^{3}$ A fegyelmezési jogról az 1723. évi CXI. tc. is rendelkezett, többek között rögzítette, hogy a gyermek tisztelettel és engedelmességgel tartozik a szüleinek. Amennyiben a gyermek erkölcsileg romlott, fékezhetetlen és engedetlen volt, az apa börtönbe zárathatta. A fiúk a teljes kort 24, a lányok 16 évesen érték el, addig apai hatalom alatt álltak. ${ }^{4}$ Az 1877 . évi XXXIII. törvénycikkben foglaltak szerint a lányok életkorukra való tekintet nélkül teljes korúvá lettek, ha házasságot kötöttek. Ezt a szabályozást az indokolta, hogy a feleség az atyja hatalma alól kikerülve a férje nagycsaládjában érvényesülő atyai hatalom alá került, így lényegében továbbra sem volt valóban teljes korú. A fiúk azonban nem szabadulhattak az atyai hatalom alól a teljes kor elérése előtt, még akkor sem, ha megnősültek. ${ }^{5}$

A patriarchális nagycsaládokban az atyai hatalom korlátlanságának csak a vallási szabályok és az észszerűség szabott határt, a 19. századra ezek a hatalmi jogosítványok a szülő és a gyermek közötti oltalmazó viszonnyá szelídültek, melyben a jogok mellett megjelentek egyéb kötelességek is. Az állam beavatkozása a magánjogi és családjogi viszonyokba - melynek során kötelezôvé tették a gyermekek oktatását, illetve lehetőséget biztosítottak az állam számára hatósági intézkedések megtételére a kiskorúak veszélyeztetettsége esetén - erősen korlátozta az atyai hatalmat és ez által jelentős változásokat indított el. ${ }^{6}$

Az 1877. évi XX. tc. (Gyámi törvény) fenntartotta az atyai hatalmat (patria potestas), de jelentősen átalakult formában mint a gyermek természetes jogainak és érdekeinek védelmére hivatott intézményt. A 15. \szerint az atyai hatalom az, amit az apa a törvényes és törvényesített gyermekei felett gyakorol. A szülőt illette az a jog, hogy a gyermek házasságához beleegyezését adja, vagy azt megtagadja, esetleg utóbb a házasságkötést megtámadja. ${ }^{7}$ A tartási kötelezettség továbbra sem az atyai hatalomból eredt, hanem a rokoni kapcsolat velejárója volt. Enyhült valamelyest a házi fegyelmezési jog, az apa már nem zárhatta/zárathatta be gyermekét, helyette javító intézetbe adhatta (26. §). Rendelkezett a törvény a szülői felügyelet gyakorlásának módjáról is. Amíg a szülők együtt éltek, az apa volt jogosult gyakorolni a szülői felügyeleti jogokat, de -

\footnotetext{
2 PAP, Magyar családjog 307.

3 BíRÓ, A közös szülői felügyelet és a különélő szülő jogai 82.

${ }^{4}$ GYÖKERES, Gondolatok a szülői felügyeleti jogról 129.

${ }^{5}$ NizsalovsZKY, A család jogi rendjének alapjai 37-38.

${ }^{6}$ KATONÁNÉ SOLTÉSZ, Család és családjog 616-630.

${ }^{7}$ KOLOSVÁRY, Magánjog 505.
} 
mivel az anyát is megillették a szülői jogok - oly módon, hogy ebből az anyát ne rekessze ki, a döntő szó minden esetben az apát illette, mely döntés meghozatala során tekintettel kellett lennie a gyermek érdekeire is. ${ }^{8}$ A szülők kötelesek voltak a gyermekeket (bevett) vallási neveltetésben részesíteni, akkor is, ha ők maguk egyik bevett valláshoz sem tartoztak. Vegyes házasságok esetében a lányok anyjuk, a fiúk apjuk vallását követték.

A fentebb felsorolt jogok gyakorlásában az apa és az anya között tehát csak a törvényi elvek szintjén volt egyenlőség, mert a gyakorlatban az apa családfösége mindig elsóbbséget élvezett. Valójában csak kevés terület volt, ahol az anya és apa egyenjogúsága érvényesült: a testi és lelki ápolás, gyógyíttatás, a gyermek erkölcsi életének óvása és gondozása mindkét szülő egyforma joga és kötelessége volt. A szülői jogokat és kötelességeket nem érintette, ha a szülők maguk is kiskorúak voltak, vagy kiskorúságukat meghosszabbították. ${ }^{9}$ Ha az apa hatalmát megvonták vagy felfüggesztették, az anya jogállása gyermekeivel szemben úgy alakult, mintha az apa meghalt volna, tehát a gyermek természetes és törvényes gyámja lett. ${ }^{10} \mathrm{~A}$ törvénytelen gyermek felett a szülői jogokat az anya gyakorolta, a tartás terhe is őrá hárult, illetve a gyermek csak az ő családjával került rokoni kapcsolatba, az apáéval nem.

1945 után jelentős változás következett be a szülői felügyeleti jogok körében, amikor az ún. atyai hatalom ún. szülői hatalomra változott. Az erről rendelkező 10470/1945. (XI. 6.) ME. sz. rendelet alapvető célja az volt, hogy deklarálja és a gyakorlatban is megvalósítsa a szülők egyenlőségét, de ezt az eredményt sokáig nem sikerült elérnie. Az egyenjogúsítási törekvésnek többek között az volt az oka, hogy a hosszan tartó háború során rengeteg férfi meghalt, sok özvegyasszonyt és árva gyermeket hagyva hátra, a megmaradt családok sorsát pedig valamiképpen rendezni kellett. Ezzel együtt - a rendelet 6. \-a szerint - amíg az apa élt, az anya szülői hatalma csak másodlagos lehetett mellette. Együtt élő szülők esetén a szülői hatalom - főszabályként tehát az apát illette meg, az anya csak akkor élhetett ezzel a jogával, ha az apa betegség, távollét vagy egyéb ok miatt akadályozva volt ebben. Ha a szülók külön éltek, akkor a szülői hatalmat az a szülő gyakorolta, akihez a gyermek került. Az apa halála után a szülői hatalmat az anya gyakorolhatta.

A legnagyobb lépést a szülői és gyermeki jogok terén a házasságról, a családról és a gyámságról szóló 1952. évi IV. törvény (Családjogi törvény, továbbiakban: Csjt.) megalkotása hozta: a szülói hatalom kifejezést szülői felügyeletre változtatta, valamint kimondta, hogy a szülői jogosultságokat mindig a gyermek érdekében kell gyakorolni. Az alkotmány (1949. évi XX. tv.) rendelkezéseinek megfelelően a házastársakat egyenlő jogokkal és kötelességekkel ruházta fel a törvény, egyúttal az anya háttérbe szorítottságát is végleg megszüntette. A szülői felügyelet gyakorlása és a gyermek eltartása mindkét szülő feladatává vált. A szülői felügyeletet az apaságból illetve az anyaságból eredeztették, tekintet nélkül arra, hogy a szülők házasságban éltek-e, mindketten jogosultak voltak annak gyakorlására, a szülői jogok pedig egyben szülői kötelességgé is váltak.

A szülői gondviselés körébe ugyanazok a feladatok tartoztak, mint napjainkban, azonban a törvény sokkal konkrétabban fogalmazott, mikor így rendelkezett (75. §): a szülők kötelessége a gyermek eltartásán túl, hogy a gyermeket gondozzák, neveljék, testi és szellemi fejlődését

\footnotetext{
${ }^{8}$ CSORNA, Rokonság 336.

${ }^{9}$ Kolosváry, Magánjog 505-506.

${ }^{10}$ KolosvárY, Magánjog 514.
} 
elősegítsék. Arra kell törekedniük, hogy a gyermek egészséges, mûvelt, erkölcsös, népéhez hű, hazáját szerető, a szocializmus építésében hasznos munkával közremúködő emberré váljék. A szülők voltak jogosultak meghatározni a gyermek tartózkodási helyét, valamint életpályáját. ${ }^{11} \mathrm{~A}$ Csjt. mellett az ifjúságról szóló törvény (1971. évi IV. tv. 3. \.) a gyermek kötelességeiről is részletesen szólt: „[...] minden fiatal kötelessége, hogy szorgalmasan tanuljon, becsületesen dolgozzon, tisztességesen éljen, védelmezze szocialista hazáját, szolgálja a társadalmi haladás és a béke ügyét. Az ifju nemzedék tekintse példaképének a társadalmi haladásért küzdö felnötteket, tisztelje szüleit, nevelöit és munkatársait" ${ }^{12}$

A Csjt. kimondta, hogy amennyiben a szülők életközössége megszűnt, az a szülő jogosult a szülői felügyeleti jogok gyakorlására, akinél a gyermeket elhelyezték. A gyermekelhelyezés lehetett közös megegyezésen alapuló, de amennyiben ez nem jött létre, a bíróság volt jogosult a gyermek elhelyezésérôl dönteni. Azt a szülőt, aki külön élt a gyermekétől, a láthatás joga illette csak meg, a szülő felügyeleti jogai a - törvény erejénél fogva - szüneteltek. ${ }^{13} \mathrm{Ez}$ némi ellentmondást tükrözött. Annak ellenére, hogy az új szabályozás igyekezett hangsúlyozni a szülők egyenjogúságát minden téren, abban az esetben, ha elváltak, ez az egyenlőség felbomlott. A gondozó szülőhöz került minden jog, a különélő szülőt pedig gyakorlatilag csak kötelességek terhelték.

Azonban - tekintettel arra, hogy a szülői egyenjogúság nem csak jogi fogalom volt a szocializmus időszakában, hanem egyfajta erkölcsi kötelesség, mely a leszármazásból egyenesen fakad - úgy tartották, hogy a szülők a gyermek érdekében akkor is kötelesek egymással együttműködni, ha jogaik lényegesen eltérnek egymástól. Az alanyi egyenjogúság elismerését és érvényesülését hivatott biztosítani a Csjt. 93.S(2) bekezdése, ${ }^{14}$ mely szerint a gyermeket érintő fontosabb ügyekben a különélő szülöt is meg kell hallgatni. ${ }^{15}$ Ilyen lényeges kérdések voltak a gyermek nevének megválasztása (és 1995-től megváltoztatása is), tartózkodási helyének kijelölése, iskolájának és életpályájának megválasztása (ez utóbbi természetesen a gyermekkel egyetértésben). A bíróság ezen kívül feljogosíthatta a különélő szülőt a törvényes képviseletre a gyermek vagyoni ügyeiben. Ugyan a végső döntést a felügyeletet gyakorló szülő volt jogosult meghozni és a szabály be nem tartásának sem volt semmiféle következménye, a társadalom hozzáállásának megváltoztatásához vezető úton fontos mérföldkőnek számított ez a rendelkezés.

Az 1995. évi XXXI. törvény ismét jelentős változásokat hozott. Alapelvi szintre emelte a tételt, miszerint a Csjt. alkalmazása során mindenkor a kiskorú gyermek érdekére figyelemmel, jogait biztosítva kell eljárni. Ez az alapelv később az egész törvényt áthatotta és az új Ptk.-ban is tovább él. Az átfogó törvénymódosítás ${ }^{16}$ célja elsősorban az volt, hogy az 1991. évi LXIV.

\footnotetext{
${ }^{11}$ Lásd PAP, Magyar családjog 265-287.

${ }^{12}$ Hatályon kívül helyezte: 1998. évi LXXXVI. tv. 77. \(2) bek. b) pontja.

${ }^{13}$ BACSÓ - RÁDY - SZIGLIGETI, A családjogi törvény 274.

${ }^{14}$ Az 1986-os Csjt. módosítás (1987. július 1-től) bevezette az együttdöntési jog fogalmát, amely a különélő szülő számára beleszólási lehetőséget jelentett a gyermek sorsát érintő lényeges kérdésekbe.

15 BACSÓ - RÁDY - SZIGLIGETI, A családjogi törvény 94-95.

${ }_{16} \mathrm{Az}$ egyezséggel rendezett viszonyok stabilitásának érdekében apróbb, de hatását tekintve annál jelentősebb változásokat is eszközöltek. Úgy mint a korábbi 18. \(3) bekezdés: „A felek tartós jogviszonyát rendezó egyezség megváltoztatását az egyezség jóváhagyásától számitott két éven belül a biróságtól - az egyéb törvényes feltételek megléte esetén is - csak akekor lehet kérni, ha a körülmények. változása folytán a megállapodás valamelyik fél vagy gyermeküke érdekét súlyosan sérti." helyébe a következő lépett: „A felek tartós jogviszonyát rendezo” egyezség megváltoztatását az egyezség jóváhagyásától számitott két éven belül a biróságtól - az egyéb törvényes feltételek megléte esetén is - csak akkor lebet kérni, ha az a felek kiskorú gyermekének érdekét szolgálja, illetve, ha a körülmények változása folytán a megállapodás valamelyik fél érdekét súlyosan sérti”.
} 
törvénnyel kihirdetett, a gyermekek jogairól szóló, New Yorkban 1989. november 20-án elfogadott ENSZ egyezménnyel összhangba kerüljön a családjogi törvény.

További jelentős változásként könyvelhető el, hogy a törvénymódosíás nyomán megkülönböztetésre került az együttes és a közös szülői felügyelet. A változtatást követően a Csjt. ekként fogalmazott: „A szülöi felügyeletet a szülök együttesen gyakorolják - ellentétes megállapodásuk biányában akkor is - ha már nem élnek együtt”. Az együttes joggyakorlás tehát arra az esetre vonatkozott, amikor a szülők együtt éltek és együtt nevelték a gyermeket, illetve, ha nem éltek együtt, de a szülői felügyeletre nézve semmiféle megállapodás, ítélet, határozat nem volt közöttük. A szülők kapcsolatának megszúnése után a felek megállapodhattak abban, illetve a bíróság jóváhagyhatta erre irányuló közös kérelmüket, miszerint a szülői felügyeletet közösen gyakorolják. $\mathrm{Az}$ együttes joggyakorlás tehát egyfajta természetes állapotnak tekinthető, a közös szülői felügyelet pedig egy jogi kötőerővel is bíró megállapodás eredménye, de tartalmát tekintve gyakorlatilag ugyanaz. A szülői felügyeleti jogok körébe tartozó azon kérdésekben, amelyben a szülői felügyeleti jogot együttesen gyakorló szülők nem tudtak egyetértésre jutni - a lelkiismereti és vallásszabadság körébe tartozó kérdések kivételével - a gyámhatóság döntött. A Csjt.-ben korábban csak egyetlen mondatból álló 71. \ is kibővült: „A szülöi felügyeletet a kiskorú gyermek érdekeinek megfelelöen kell gyakorolni. A szülöknek biz̨tositaniuk kell, hogy az itélöképessége birtokában lévö gyermeküle az ôt érintö döntések elökészitése során véleményt nyilvánithasson. A gyermek véleményét - korára, érettségére figyelemmel - tekintetbe kell venni".

Összefoglalva nem csupán Magyarország tekintetében, hanem világszerte elmondható, hogy az utóbbi évtizedekben sokat változtak a szülői felügyeleti jog gyakorlásának elvei. A kifejezés, ami az ókortól kezdve egészen sokáig atyai hatalmat jelentett, csak a 19. század végén változott szülői hatalommá, majd a 20. század folyamán szülői felügyeletté. A közelmúlt nemzetközi dokumentumaiban pedig már nem a felügyelet (custody), hanem a szülői felelősség kifejezés (parental responsibility) szerepel mint a szülők kiskorú gyermekkel kapcsolatos jogainak és kötelezettségeinek összefoglaló megjelölése.

A szülői felelősség mint gyüjtőfogalom merőben mást, többet jelent, mint a szülői hatalom. Az új megközelítés hatására a korábbi alá-fölérendeltségi viszony helyébe egyértelműen mellérendeltségi viszony lépett. ${ }^{17} \mathrm{Ma}$ már minden családjogi rendszer alapja a gyermek legfôbb érdeke, ami korábban nem volt ennyire domináns. A Polgári Törvénykönyvről szóló 2013. évi V. törvény (a továbbiakban Ptk.) előkészítése során felmerült, hogy a magyar szabályozásban is új kifejezést kellene találni a megszokott, de nem kellően kifejező ún. szülői felügyelet helyett, azonban ezt végül elvetették. ${ }^{18}$

\section{A gyermekelhelyezés szabályainak jogtörténeti előzményei}

A gyermekelhelyezés szabályozásának szükségessége a kánoni, szentségnek tekintett házasság felbonthatatlansága miatt a szekularizáció koráig nem mutatkozott meg. Ahol és amikor pedig a bontás lehetősége adott volt, nem éltek ezzel gyakran, és főként nem olyan rövid házasság után, hogy a gyermekek még kiskorúak lettek volna. Másrészt az atyai hatalom korlátlansága ebben a kérdésben is dominált.

\footnotetext{
${ }^{17}$ SOMFAI, Családjogi és/vagy gyermekvédelmi jogviszony 548.

${ }^{18}$ KŐRÖs, Fontolva haladás $1-8$.
} 
A 19. században a gyermekelhelyezésnél még annak volt kiemelkedő jelentősége, hogy melyik fél volt vétkes a házasság megromlásában. Ha a szülők másként nem egyeztek meg, minden gyermek felett a közvetlen gondviselés joga a házasság megromlásában nem vétkes szülőt illette, ${ }^{19}$ azzal a megkötéssel, hogy 7 éves kor alatt a gyermek gondviselésének joga - szinte minden esetben - az anyát illette, mivel úgy tartották, hogy a kicsi gyermeknek az édesanyja mellett a helye. A hét évesnél idősebb fiúkat általában az apjuknál helyezték el, mert úgy vélekedtek, hogy egy serdülőkorú fiú érdekével ellentétes, hogy erélytelen női nevelésben részesüljön. ${ }^{20}$ Abban az esetben, ha mindkét szülő vétkes volt, a fiúk gondviselése az atyát, a leányoké az anyát illette, de csak akkor, ha a gyermekek nyilvánvaló érdeke más elhelyezést nem tett a hatóság kötelességévé. Ennek során harmadik személynél is elhelyezhették a gyermeket. ${ }^{21}$

A gyámsági és gondnoksági ügyeket szabályozó 1877. évi XX. tc. szerint amennyiben a szülők között megszűnt az életközösség, függetlenül attól, hogy ki kezdeményezte a házasság felbontását, a lányok és a hét év alatti fiúk az anyákhoz kerültek, ha nem tudtak megállapodni arról, hogy a továbbiakban ki gyakorolja a szülői felügyeleti jogokat. Ha a gyermekek az anyához kerültek, az apa atyai hatalma csak odáig terjedt, hogy velük kapcsolatot tarthatott és nevelésüket ellenőrizhette..$^{22}$ Amint Fodor Ármin írta, „šüleségszerüen a bontóper tárgyává kellett tenni a gyermek létezésének vagy nem létezésének kérdését, még akekor is, ha gyermek a felbontandó házasságból nem született. Amennyiben létezett közös kiskorú gyermek, úgy ennek végleges elhelyezése és tartása, valamint a tartás biztositása kérdését okvetlenül a per tárgyává kellett tenni, mert a gyermek sorsáról a bíróság hivatalból is gondoskodott". 23

Az 1894. évi XXXI. tc. (Ht.) rendelkezései szerint, ha a szülők már nem éltek együtt vagy házasságuk felbomlott, a gyermekek elhelyezése vonatkozásában egyezséget köthettek. Amennyiben ez nem jött létre, vagy azt nem tartották be, akkor a gyámhatóság vagy a házassági per bírósága volt jogosult a kérdésben dönteni. Amennyiben az összes gyermek az anya gondviselésébe került, az anya önálló jogálláshoz jutott. ${ }^{24}$ A felbontott házasságból származó gyermekek a felbontás ellenére is törvényes gyermekek maradtak, aminek kiemelkedő jelentősége volt.

A Ht. az ágytól és asztaltól való elválasztást a kibékülés illetve megfontolás céljából alkalmazta. Az elválást ideiglenesnek tekintették, és meghatározott időtartamra rendelték el (6 hó). Segítségével a felek eldönthették, hogy tovább lépnek-e, azaz felbontják a házasságukat, vagy pedig helyreállítják az együttélést. Az ítéletben rendelkezni kellett a nőtartásról, a közös kiskorú gyermek elhelyezéséről, a tartásáról, a gondozásáról, a neveléséről, valamint a feleség részére egyes tárgyak kiadásáról, de lehetőség volt ideiglenes gyermekelhelyezésre is. ${ }^{25}$

A gyermekelhelyezés szabályozásában a 20. század első felében csekély változás következett be. Az 1921. évi LIV. tc. 21. \-a szerint a gyermek elhelyezésének és tartásának kérdésében a legközelebbi rokonok meghallgatásával ideiglenesen a gyámhatóság határozott. Ezt a rendelkezést az 1930. évi XXXIV. tc. 137. \-a hatályon kívül helyezte: a házassági per során a

\footnotetext{
${ }^{19} \mathrm{Vö.} \mathrm{Ht.} \mathrm{95.} \mathrm{§}$

${ }^{20}$ KATONÁNÉ SOLTÉSZ, Család és családjog. 114.

${ }^{21}$ Ht. 95. $\int$

22 FODOR, Magyar magánjog 721.

${ }^{23}$ FODOR, Magyar magánjog 349.

${ }^{24}$ KOLOSVÁRY, Magánjog 513-514.

${ }^{25}$ FODOR, Magyar magánjog 350.
} 
gyermek elhelyezéséről a bíróság határozott, akkor is, ha korábban a gyámhatóság már döntött. ${ }^{26}$ Az ideiglenes nemzeti kormány 1945. augusztus 16-án fogadta el a 6800/1945 ME. rendeletet, melyben a vétkességi alapú bontás elveit megtartották, de az eljárást egyszerűbbé, gyorsabbá és olcsóbbá tették, illetve további három bontó okot nevesítettek. A rendelettel bevezetett új eljárás már gyakorlatilag a közös megegyezéses bontás előfutára volt, azzal a különbséggel, hogy csak a nőtartásra, a névviselésre és egyes vagyoni kérdésekre terjedt ki a megállapodás, a gyermek elhelyezéséről és tartásáról az ítélet meghozatalát követően a gyámhatóság döntött, hiszen a leegyszerűsített peres eljárásban nem volt lehetőség a gyermek érdekét szolgáló körülmények feltárására. ${ }^{27}$ 1940-ben Csorna Kálmán megfogalmazott egy elvárást, melynek kisvártatva eleget is tett a jogalkotó: „A magyar törvényben foglalt vétkességi elvvel szemben számos külföldi törvény a bontóper birájának engedi át azt a jogot, hogy szabad mérlegelés alapján a gyermeket egyik vagy másik szülönek adja gondozásba. Már ez a rendelkezés is bizonyos baladást jelent e téren, de a leginkább megfeleló és kivánatos megoldás az lenne, amely kizárólag a gyermekek érdekéböl indulna ki, vagyis abból a kritériumból, hogy melyik szüló alkalmasabb a gyermek gondozására és nevelésére”."

Az 1952. évi IV. törvény 72/A \-a szerint „A gyermek elhelyezéséröl a szülök döntenek. A šülök megegyezésének biányában a bíróság a gyermeket annál a szülónél helyezi el, akinél a kedveróbb testi, értelmi és erkölcsi fejlödése bižtositott. Ha a szülönél történö elhelyezés a gyermek érdekét veszélyezteti, a biróság a gyermeket másnál is elhelyezheti, feltéve, hogy ez a személy a nála történó elhelyezést maga is kéri”. Önmagában a gyermek nemének és életkorának nem lehet döntő szerepe az elhelyezésnél. A gyermek neme és kora csak az ügy valamennyi körülményének egymással összefüggésben történő vizsgálata során értékelhető, különösen azzal kapcsolatosan, hogy a gyermek nemére és korára tekintettel melyik házastárs mutatott több és jobb nevelési készséget. ${ }^{29}$

Hibás bírósági gyakorlatra utal, hogy a bíróság sokszor úgy értelmezte a Csjt. ide vonatkozó rendelkezéseit, hogy csak abban az esetben kell a gyermek elhelyezése érdekében eljárniuk, amennyiben a szülők ebben a kérdésben nem egyeztek meg. Gellért György hangsúlyozta, hogy a bíróságnak a szülők egyezségkötése esetén is minden esetben vizsgálnia kell, hogy az megfelel-e a gyermek érdekének, nem lehet tehát automatikusan jóváhagyni a felek egyezségét megnyugodván abban, hogy a szülők úgyis biztosan a legjobbat akarják gyermeküknek. Pláne, hogy a békítés egyik lehetôségét is látták benne, mondván hátha a szülők felelősségérzete felébred és rájönnek, hogy az a legjobb a gyermek számára, ha továbbra is együtt nevelik. ${ }^{30}$

Az ötvenes évek elején a bíróságok még igyekeztek mindent elkövetni annak érdekében, hogy a szülők együtt maradjanak, ha kiskorú gyermekük van: „a cél a sqülók megszakadt életközösségének mielóbbi visszaállitása, a nevelö, gondozó munka együttes teljesitése érdekében”. „Nagyobb gyermeknél különösen ą̧t is szem elött kell tartani, hogy tanulmányaik szempontjából, jövö boldogulásuk megalapozása érdekében és erkölcsi felfogásuk kialakitására nézve döntó jelentöségü lehet az, hogy milyen változás megy végbe a családjukon belül, hogy szüleik. között ismét helyreáll-e a példás össz̧hang, a békés, egymást támogató megértés légköre". ${ }^{2}$

\footnotetext{
${ }^{26}$ CSORNA, Rokonság 260.

${ }^{27}$ CSERBÁNÉ NAGY, A házassági jog kodifikációi 79-80.

28 CSORNA, Rokonság 342.

${ }^{29}$ LB. 17.sz. irányelv.

${ }^{30}$ GELLÉRT, A gyermek elhelyezése 368-369.

31 Pf.I.22.294/1953

32 Pf.I.22.726/1953
} 
Hosszú ideig tartotta magát az az elképzelés, hogy a gyermeknek ép családban kell felnőnie és az egészséges fejlődése érdekében mindkét szülőjére szüksége van. Úgy gondolták, hogy abban az esetben, ha a gyermek ragaszkodik a szüleihez és a szülók is szeretik gyermeküket, van remény a házastársak ellentétjeinek feloldására, kölcsönös sérelmeik orvoslására. Ezen célt szem előtt tartva vezették be az ún. békítő tárgyalásokat bontóperekben és a bíróságnak különös gondot kellett fordítani a békítésre, ha a feleknek közös kiskorú gyermeke volt. Ez azt jelentette, hogy a bíróság köteles volt az első tárgyalás előtt a házasfeleket meghallgatni és megkísérelni a békítésüket. Amennyiben ennek értelmét látta, a bíróság az eljárás bármely szakaszában újra megkísérelhette a békítést. A bíróságnak tehát tevékenyen közre kellett múködnie, ha azt tapasztalta, hogy az életközösség helyreállítása valamilyen akadály kiküszöbölésével elősegíthető, így elég mélyen bele kellett vonódnia a család magánügyeibe, de mindezt kizárólag a gyermek érdekében tette. A Legfelsőbb Bíróság bontóperben kötelező 9. számú Irányelve kimondta, hogy a bíróságnak körültekintően vizsgálnia kell azt, hogy a házasság felbontása vagy a kereset elutasítása milyen hatással járhat a gyermek sorsának alakulására. A békítés sikertelensége esetén is arra törekedtek, hogy a házasság megszűnése a gyermek számára a lehető legkisebb megrázkódtatást okozza. ${ }^{33}$

A gyermek érdekében általában kívánatos volt a házasság fenntartása, de minden körülményt megvizsgálva, elképzelhető volt, hogy jobban szolgálja a gyermek érdekeit, ha a szülők elválnak. „A gyermek helyes irányba való erkölcsi fejlödése és nevelésének érdeke, a feldúlt és tarthatatlanná vált házasság felbontását kívánja. ${ }^{\not 34}$ Ha a gyermek még nagyon kicsi volt, akkor a bíróság kötelessége volt, hogy a sértődött szülőket „türelmes nevelő munkával” kibékülésre bírja. Ha ez nem sikerült, tehát, ha dönteni kellett a gyermek elhelyezéséről, akkor a bíróság a következő tényezőket vizsgálta: szülői szeretet, kötelességtudat, felelősségérzés, illetve azt, hogy van-e remény arra, hogy a szülők a gyermek kedvéért kibékülnek. A szülők személyiségét, személyi körülményeit, egyéniségét és életviszonyait a bíró önmaga ítélte meg, szakértő igénybe vétele nélkül.

A Csjt. 1952. évi - eredeti - szövegezése megtartotta az életkor és nem szerinti különböztetést. Kihagyta ugyan a vétkességet, de úgy rendelkezett, hogy a hat év feletti fiúk az apához, a hat év alatti fiúk és a lányok az anyához kell, hogy kerüljenek - rendszerint. ${ }^{35} \mathrm{Nem}$ kevés bonyodalmat okozva ezzel, mert annak ellenére, hogy a jogszabály úgy fogalmazott: rendszerint, tehát nem minden esetben, és kimondta, hogy a gyermek érdekében ettôl a szabálytól el lehet térni, a bíróságok a szülők megegyezése hiányában - egy rövid ideig - szinte mechanikusan alkalmazták a gyermekelhelyezés eme nem túl korrekt és a gyermek igényeire egyáltalán nem érzékeny módját. A korábbi hétéves korhatárt pedig azért változtatták hat évre, mert úgy ítélték meg, hogy a gyermekek értelmi fejlődése felgyorsult, fiatalabb korban is kezdik az iskolát, mint korábban. ${ }^{36}$

A jogirodalomban alapelvnek tekintették, hogy olyan megoldást kell találni, amely a legjobban biztosítja a gyermek jövőbeni erkölcsi és testi fejlődését, illetve, hogy az itélet

\footnotetext{
33 KATONÁNÉ SOLTÁSZ, Család és családjog 94-102.

34 Pf. III. 23.048/1953

${ }^{35}$ Csjt. 76. \,A gyermek elhelyezése kérdésében - a szülók megegyezése hiányában - a biróság dönt. Ilyen esetben a hatodik. életévét betöltött fiúgyermeket rendszerint apjánál, a leánygyermeket és a batodik életévét be nem töltött fiúgyermeket pedig rendszerint anyjánál kell elhelyezni. A gyermek érdekében azonban ettöl a szabálytól el lehet térni, söt a gyermeket máshol is el lehet helyezni."

${ }^{36}$ BACSÓ - RÁDY - SZIGLIGETI, A családjogi törvény 275.
} 
meghozatala során kizárólag a gyermek érdekét kell szem előtt tartani. ${ }^{37}$ Ezt azonban egy hibás jogértelmezéssel lényegesen megnehezítették. A téves értelmezés egy Legfelsőbb Bírósági határozaton alapult. 1952-1959-ig egységes gyakorlatot tapasztalunk a bíróságokon, minden ügyben kiemelt figyelmet szenteltek a gyermek érdekeinek és csak másodlagosan vették figyelembe az életkort és a gyermek nemét. A rossz irányba mutató gyakorlat a Legfelsőbb Bíróság elnökségi tanácsának P.22937/1958.sz. (BH. 1959.4. sz. 2254.) határozatával kezdődött, amely szintén a gyermek mindenekfelett álló érdekét hangsúlyozza, azonban nyomatékosan kiemeli a kor és a nem szerinti hovatartozás jelentőségét. Ez aztán a bírák körében egy olyan téves értelmezéshez vezetett, mely szerint a gyermek elhelyezésénél a legfőbb szempont a nem és az életkor, amelyet minden esetben szinte mechanikusan alkalmaztak. ${ }^{38} \mathrm{~A}$ határozat így szólt: „, $a$ gyermek elhelyezésénél a hatodike életév betöltése után általában a nemük az irányadó, a törvény rendelkezése tebát az, hogy a batodik életévïket betöltött fiugyermekek az apjuknál, a leánygyermekek pedig az anyjuknál belyeztessenek el, s ettöl a szabálytól-megegyezés hiányában - csak a gyermek érdekében lehet eltérni. A törvényi rendelkezéstól eltérö elhelyezést a biróság akeor állapithat meg, tehát akekor rendelkezhet úgy, hogy a hatodik életévét betöltött fiúgyermeket nem az apjánál, hanem az anyjánál, a hatodik életévét betöltö̈t leánygyermeket pedig nem az anyjánál, hanem az apjánál helyezi el, ha ez a gyermek érdekében áll. Ilyen eltérés esetén azt az érdeket, amely az eltérést indokolja, megalapozottan meg kell állapitani."

Az értelmezési probléma abból eredt, hogy a bíróságok kiragadták a szövegből a fent idézett bekezdést és azt alkalmazták, holott a határozat így folytatódik: „A gyermek érdekei

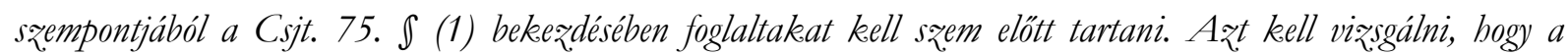
gyermek gondozása, nevelése, testi és szellemi fejlödése melyik szülónél van inkább biz̨tositva. Melyik szü̈lö képes inkább arra, hogy a közös gyermekülk egészséges, müvelt, erkölcsös, népéhez, hü, hazáját szeretố, a szocializmus épitésében haszৃos munkával közremüködö emberré nevelödjéke”. A Legfelsőbb Bíróság hamar felismerte e gyakorlat helytelenségét és az 1960. szeptember 15-én hozott P.törv.21302/1960.sz. határozatában kifejtette, hogy a gyermekelhelyezés szempontjaira vonatkozó rendelkezést nem lehet a törvény egyéb rendelkezéseitől elvonatkoztatva alkalmazni, hanem az a döntő, hogy a gyermek érdeke milyen elhelyezést kíván. ${ }^{39}$ A köztudatban azonban olyannyira elterjedt a nézet, hogy a hat évnél idősebb fiúgyermek nevelése az apa joga, hogy egyes apák a fiúk 6. születésnapját követôen beszüntették a tartásdíffizetést, mondván, hogy a gyermeket mostantól ők nevelik majd. Sok édesanya engedelmeskedett és átadta a fiút az apának, sokan pedig inkább önként lemondtak a tartásdíjról, csak hogy továbbra is ők nevelhessék gyermeküket. ${ }^{40}$ A jogirodalom ugyan ezzel ellentétes álláspontra helyezkedett, de a szülők ezzel nem voltak tisztában. Bacsó Jenô és szerzôtársai véleménye szerint a bíróság mellőzi a gyermek komoly ok nélküli elvételét attól,

\footnotetext{
${ }^{37}$ CSIKI - SIMOR, A családjogi tartási kötelezettség, gyermekelhelyezés 231.

${ }^{38}$ CSIKI - SIMOR, A családjogi tartási kötelezettség, gyermekelhelyezés 232.

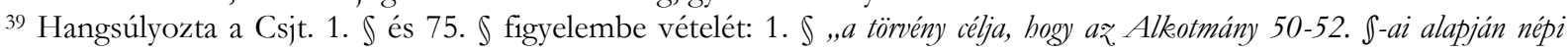
demokeráciánk társadalmi rendjének és a szocialista erkölcsi felfogásnak megfelelöen szabályozza és védje a házasság és a család intézményét, biztositsa a házasságban és a családi életben a nök egyenjogúságát, a gyermekek érdekeinek védelmét és elömozdítsa az. ifjúság fejlödését és nevelését.” 75. „A szülöi felügyelet körében a sqülök kötelessége, hogy a gyermeket gondozzák, neveljék, testi és szellemi fejlödésében elösegitsék. Arra kell törekedniük, hogy a gyermek egészséges, müvelt, erkölcsös, népébez bü, hazáját szueretöó, a szocializmus épitésben hasznosan közremüködö emberré váljék. Joguk és kötelességük mindent megtenni, ami e célok elérése érdekében szülkéges és tartózkodniuk. kell mindentöl, ami azok elérését akadályozza vagy megnehezíti."

${ }^{40}$ CSIKI - SIMOR, A családjogi tartási kötelezettség, gyermekelhelyezés 238.
} 
akinél hosszabb ideje elhelyezte, nehogy a gyökeres környezetváltozás kárára váljék. Pl.: nem lehet az apának átadni a fiút, csak azért, mert elmúlt hat éves. ${ }^{41}$

A gyermekelhelyezés szempontjainak tisztázása érdekében született meg végül 1961-ben a XXI. számú PED ${ }^{42}$ (BH. 1961.3.sz.), ami már egyértelműen leszögezte, hogy az életkor és a gyermek neme csak egy a sok vizsgálandó szempont közül, a legfontosabb, hogy a gyermek fejlődése melyik szülőnél biztosítható jobban. Ezzel együtt a korra és nemre való utalás csak az 1974. évi módosítással került ki a törvény szövegébőll. ${ }^{43}$ A hetvenes években már fontosnak tartották külön kiemelni, hogy „a törvény nem köti az elhelyezést a gyermek korához, neméhez, hanem alapvetönek a gyermek érdekét tekinti"»4. A XXI. PED rendelkezett továbbá arról is, hogy a bíróságnak minden esetben vizsgálnia kell azt, hogy a szülők egyezsége valóban alkalmas-e a gyermek érdekeinek szolgálatára, amennyiben úgy találta, hogy nem, nem volt köteles jóváhagyni az egyezséget, azzal ellentétes döntést is hozhatott. ${ }^{45}$ Ezen iránymutatás a mai napig helytálló elvileg. A gyakorlatban ugyanis a bíróság nem folytatja le a bizonyítási eljárást, ha a felek közös megegyezéssel kérik a házasság felbontását és/vagy a szülői felügyelet rendezését. Ebből kifolyólag nem áll rendelkezésükre kellő mennyiségú információ, amely alapján megítélhetnék, hogy melyik szülőnél való elhelyezés szolgálja a gyermek érdekét.

A Legfelsőbb Bíróság P.törv.25.661/1962 sz. határozatában kifejtette, hogy amennyiben a bíróság úgy ítéli meg, hogy egyik szülő sem alkalmas a gyermek nevelésére, kezdeményezheti a gyámhatóságnál a gyermek állami gondozásba vételét. A gyámhatóság döntéséig a pert fel kellett függeszteni, és ha a gyámhatóság az állami gondozásba vételt nem tartotta indokoltnak, akkor további bizonyítási eljárás lefolytatásának eredményeként kellett a gyermek elhelyezéséről dönteni.

\section{3. Összegzés}

A szülőket gyermekeikkel kapcsolatosan megillető jogok és kötelességek nagyívű változásokon mentek keresztül az antikvitás óta, amikor a pater familias még korlátlan hatalommal rendelkezett háza népe, így a gyermekei felett is. Az anyákat hosszú időn keresztül semmiféle jogok nem illették, hiszen ôk maguk is férjeik vagy apósuk hatalma alatt álltak. Az apák széleskörû hatalma egészen a középkorig tartotta magát. Először John Lockee vetette fel, hogy az anyának és az apának közösen kellene a szülői jogokat gyakorolni. Javaslata csak évszázadokkal később került át a gyakorlatba. A helyzet Magyarországon is hasonlóképpen alakult. A keresztény vallás felvétele után az apák jogai meggyengültek, kötelességeik azonban fokozódtak, ugyanakkor az anyák háttérbe szorítottsága továbbra is megmaradt. A 19. századra az atyai hatalom fokozatosan átalakult, először szülői hatalommá. A gyermek jogainak és érdekének védelme lassan bekerült a joggyakorlatba, majd a köztudatba is. Az 1952. évi IV. törvény hatályba lépése jelentette a legfontosabb mérföldkövet és hozta a legjelentősebb változásokat. A szülői hatalom szülői felügyeletté változott.

\footnotetext{
${ }^{41}$ BACSÓ - RÁDY - SZIGLIGETI, A családjogi törvény 277.

42 „A gyermek elhelyezése vagy eddigi elhelyezésének megváltoztatása iránt indult perben a bíróságnak minden esetben gondosan vizsgálnia kell a gyermek érdekét és döntésénél ežt kell föszempontnak tekintenie. Ha a szülöknek a gyermek elhelyezése kérdésében kötött megegyezése a gyermek érdekével ellentétes, a házassági per bírósága a megegyezés félretételével az elhelyezés kérdésében bivatalból úgy intézkedhet, ahogy az a gyermek érdekének legjobban megfelel."

${ }^{43}$ CSIKY - FILÓ, Családjog 60.

${ }^{44}$ BACSÓ - RÁDY - SZIGLIGETI, A családjogi törvény 121.

45 PETRIK, Az állam beavatkozása a szülői felügyelet gyakorlásába 34.
} 
Ami a szülői felügyelet rendezését illeti, a változások radikálisak voltak, azonban rendkívül lassan zajlottak. Sokáig egyáltalán nem volt szükség a kérdés szabályozására, hiszen egyértelmû volt, hogy a jogokat az apa gyakorolja, illetve a házasság felbontására sem volt gyakran példa. Miután a válások egyre szélesebb kört kezdtek érinteni szükségessé vált a helyzet megnyugtató rendezése érdekében a részletszabályok megfogalmazása, mely hosszú ideig a szülők vétkességén alapult és kiemelt jelentőséget tulajdonított a gyermek nemének és életkorának. Az 1952-ben elfogadott Csjt. a gyermekelhelyezést is szabályozta a szülők kapcsolatának megszúnése esetére, mely szabályok a Ptk. 2014-es hatályba lépéséig több alkalommal is finomodtak. Az új törvény annak ellenére, hogy magát a kifejezést nem használja - valójában egészen új alapokra helyezte a szülői felelősséget, amely kicsit több, kicsit más, mint a szülői felügyelet, egyúttal a szülők közös felelősségét hangsúlyozza. A számtalan új lehetôség ellenére - mint például váltott elhelyezés és a fészek modell - a közös szülői felügyelet még mindig nem túl jellemző, a jogok és kötelezettségek összessége jellemzően még midig az anyákat illeti/terheli, pedig a megváltozott szülői szerepek miatt az apák egyre nagyobb szerepet kívánnak játszani gyermekeik életében, és egyre inkább jellemző, hogy nem hagyják magukat félre állítani, hanem megküzdenek azért, hogy az anyákkal nagyjából azonos jogaik legyenek, tehát újabb változások kapujában állunk.

\section{Felhasznált irodalom és források}

BACSÓ Jenő - RÁDY Géza - SzIGLIGETI Viktor: A családjogi törvény. Budapest 1955

Bíró Eszter: A közös szülői felügyelet és a különélő szülő jogai. In: FÓNAI Mihály - CsŰrÖs Gabriella (szerk.): Studia Iuvenum ad 2009. Debrecen 2009, 79-93.

CSERBÁNÉ NAgY Andrea: A házassági jog kodifikációi. PhD értekezés, Miskolc 2012

CSIKI Ottó - SIMOR Antal: A családjogi tartási kötelezettség, gyermekelhelyezés. Budapest 1962

CsIKY Ottó - FILÓ Erika: Családjog II. Pécs 1988

CSORNA Kálmán: Rokonság. In: SZLADITS Károly (szerk.): Magyar magánjog II. Budapest 1940, 294-369.

GELLÉRT György: A gyermek elhelyezése. Magyar Jog 1960/9. sz. 368-369.

GYÖKERES Csilla: Gondolatok a szülöi felügyeleti jogról. Acta Juridica et politica. Szeged 1993

FODOR Ármin (szerk.): Magyar magánjog IV. Családjog. Budapest 1897

KATONÁNÉ SoltéSz Márta: Család és családjog. A családjog központi intézménye: a házasság. Magyar Jog 1987/78. sz. 616-630.

KOLOSVÁRY Bálint: Magánjog - a magyar magánjogból tartott egyetemi előadások rövid vázlata, harmadik átdolgozott és bővített kiadás. Budapest 1930

KŐRÖS András: Fontolva haladás - az új Ptk. Családjogi Könyve. 6. rész: A szülői felügyelet I. és II. fejezet. Családi Jog 2006/3. sz. 1-8.

NIZSALOvSZKY Endre: A család jogi rendjének alapjai. Budapest 1963

PAP Tibor: Magyar családjog. Budapest 1976

PETRIK Ferenc: Az állam beavatkozása a szülői felügyelet gyakorlásába. Állam és Igazgatás 1969/1. sz. 29-43.

SOMFAI Balázs: Családjogi és/vagy gyermekvédelmi jogviszony. In: NOCHTA Tibor - FABÓ Tibor - MARTON Mária (szerk.): Ünnepi tanulmányok Kecskés László professzor 60. születésnapja tiszteletére. Pécs 2013, 543-552.

VADÁSz Lajos (szerk.): Magánjogi Törvénykönyvünk és első tételes jogunk I. kötet, Személyi-, családi- és dologi jog. Budapest 1929 